\title{
Platinated DNA oligonucleotides: new probes forming ultrastable conjugates with graphene oxide
}

\author{
Feng Wang a and Juewen Liu ${ }^{\mathrm{a}, *}$ \\ Received (in $X X X, X X X)$ Xth $X X X X X X X X X 20 X X$, Accepted Xth $X X X X X X X X X 20 X X$ \\ ${ }_{5}$ DOI: $10.1039 / \mathbf{b 0 0 0 0 0 0 x}$
}

\begin{abstract}
Metal containing polymers have expanded the property of polymers by involving covalently associated metal complexes. DNA is a special block copolymer. While metal ions are known to influence DNA, little is explored on its polymer property when 10 strong metal complexes are associated. In this work, we study cisplatin modified DNA as a new polymer and probe. Out of the complexes formed between cisplatin/ $\mathrm{A}_{15}, \mathrm{HAuCl} / \mathrm{A}_{15}, \mathrm{Hg}^{2+} / \mathrm{T}_{15}$ and $\mathrm{Ag}^{+} / \mathrm{C}_{15}$, only the cisplatin adduct is stable under the denaturing gel electrophoresis condition. Each Pt-nucleobase 15 bond gives a positive charge and thus makes DNA a zwitterionic polymer. This allows ultrafast adsorption of DNA by graphene oxide (GO) and the adsorbed complex is highly stable. Nonspecific DNA, protein, surfactants and thiolated compounds cannot displace platinated DNA, while non-modified DNA is 20 easily displaced in most cases. The stable GO/DNA conjugate is further tested for surface hybridization. This is the first demonstration of using metallated DNA as a polymeric material for interfacing with nanoscale materials.
\end{abstract}

\section{Introduction}

${ }_{25}$ DNA is a polymer composed of phosphate, pentose and four types of nucleobases. These simple building blocks have already enabled complex biological and chemical functions including storage of genetic information, molecular recognition and catalysis. ${ }^{1}$ The function of DNA can be 30 further expanded by introducing covalent modifications such as optical and electrochemical labels, modified backbone or bases. $^{2}$

In addition, the property of a DNA is also influenced by metal ions. Since DNA is a polyanion, metal ions bind to its 35 backbone phosphate via electrostatic attraction, although the affinity is often weak and the association is transient. DNA bases are good ligands for transition metals. ${ }^{3}$ Well known examples include the binding of $\mathrm{Hg}^{2+}$ by thymine, ${ }^{4} \mathrm{Ag}^{+}$by cytosine,${ }^{5}$ and $\mathrm{Au}^{3+}$ by adenine and cytosine (see Figure 1A). ${ }^{6}$ 40 In more complex systems, a few DNA bases may form 3D binding pockets to interact with metal ions. The best examples are metal-specific aptamers and DNAzymes, where $\mathrm{Pb}^{2+}, 7$ $\mathrm{Zn}^{2+},{ }^{8-10} \mathrm{Hg}^{2+},{ }^{4,11} \mathrm{UO}_{2}{ }^{2+},{ }^{12}$ and lanthanides ${ }^{13,14}$ are selectively associated. Given these developments, most metal ions bind 45 reversibly to DNA with fast exchange rates, thus disqualifying them as modified DNA.

Stable metal-DNA complexes are formed in a few cases, where they often involve Group 8B metals. For example, $\mathrm{Ru}^{2+}$ and $\mathrm{Os}^{2+}$ complexes form adducts with DNA, which are stable 50 in electrospray ionization (ESI) mass spectrometry conditions. Their coordination and binding energy to DNA bases have been predicted by DFT calcutions. ${ }^{15}$ Dirhodium complexes coordinate with the $\mathrm{N} 7$ and $\mathrm{O} 6$ positions on guanine. ${ }^{16}$ Osmium tetraoxide reacts with both the ribose and thymine ${ }_{55}$ bases. ${ }^{17}$ The best known example is the adduct formed between cisplatin and guanine or adenine (Figure 1A). Cisplatin is the most successful and important anti-cancer drug. ${ }^{18-21}$ Its interaction with DNA has been extensively studied. ${ }^{22}$ Cisplatin favorably reacts with the N7 position of 60 adenine and guanine to form stable adducts.

DNA-metal adducts are called metallated DNA, where a metal center directly forms a strong covalent bond with DNA. Metallated DNA is different from metallized DNA. In a metallized DNA, metal nanoparticles are formed around a ${ }_{65}$ DNA template, ${ }^{23,24}$ and DNA plays only a sacrificial structural role. ${ }^{25}$ While metallated DNA is an important topic in medicine and have been proposed for microscopy-based DNA sequencing, ${ }^{26}$ they have not been studied as a new polymer or an analytical probe, and its interaction with nanomaterials has 70 not been explored. Many synthetic metal containing polymers have been grafted onto DNA, ${ }^{27}$ and many metal containing polymers have been prepared, ${ }^{28}$ but direct metal/DNA bonding is rare in this context. We are interested in metallated DNA since they may achieve new properties that cannot be 75 easily realized by traditional organic modifications. Herein, we explore the reaction between cisplatin and DNA and compare it with other metal ions. As an example of application, the cisplatin-DNA adduct is highly stably adsorbed by graphene oxide (GO).

80

\section{Results and Discussion.}

Metal affinity comparison. To qualify for metallated DNA, metal binding has to be strong enough and stable. For example, when free metal ions are removed, the associated 85 metal should still bind the DNA. Usually, transition metal ions bind to DNA more strongly than alkaline earth metals do. The binding strength with DNA follows the order of $\mathrm{Mg}^{2+}<\mathrm{Co}^{2+}<\mathrm{Ni}^{2+}<\mathrm{Mn}^{2+}<\mathrm{Zn}^{2+}<\mathrm{Cd}^{2+}<\mathrm{Cu}^{2+}<\mathrm{Ag}^{+}<\mathrm{Hg}^{2+} .{ }^{29} \quad$ The affinity for $\mathrm{Au}^{3+}$ and $\mathrm{Pt}^{2+}$ should be even higher. For example, 90 the bond energy is calculated to be 94.1 and $117.9 \mathrm{~kJ} / \mathrm{mol}$ for $\mathrm{Pt}^{2+}$ binding to adenine and guanine binding respectively. ${ }^{30}$ 


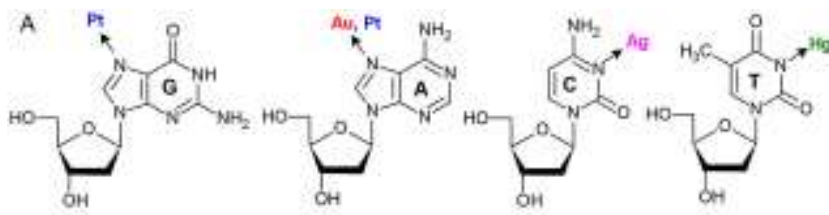

B NF.A.EN DN + Cisplasin $(\mu M)$

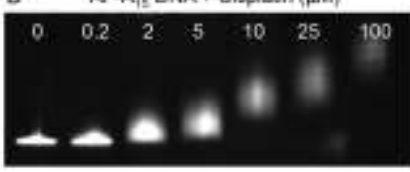

C $\quad \mathrm{AF}=\mathrm{A}_{45} \mathrm{DNA}+\mathrm{HANCl}_{4}(\mathrm{HM})$

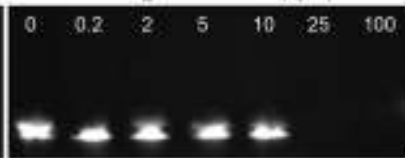

D FAM $C_{5}$ DNA $+A g^{*}($ MM)
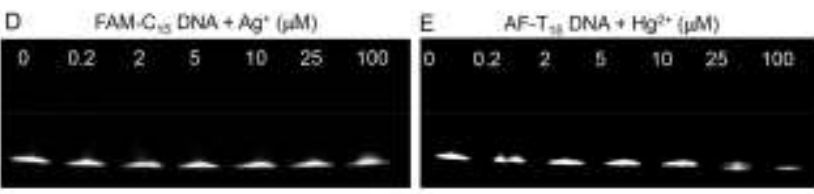

F

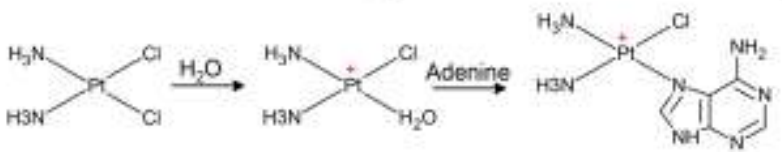

Figure 1. (A) Coordination of metal ions by various DNA 5 bases. Denaturing gel images of $\mathrm{AF}-\mathrm{A}_{15}$ reacting with various concentrations of cisplatin (B), or with $\mathrm{HAuCl}_{4}$ (C); FAM-C 15 with $\mathrm{Ag}^{+}$(D) and $\mathrm{AF}-\mathrm{T}_{15}$ with $\mathrm{Hg}^{2+}$ (E). The DNA concentration was fixed at $0.5 \mu \mathrm{M}$. (F) Reaction scheme between cisplatin and adenine, producing a positive charge on 10 the adduct.

To systematically compare the stability of the complexes formed between DNA and metal ions, we chose four high affinity systems. In the first two cases, an $\mathrm{A}_{15}$ DNA (e.g. a 1515 mer DNA with all adenine bases) is respectively reacted with cisplatin and $\mathrm{HAuCl}_{4} . \mathrm{Pt}^{2+}$ and $\mathrm{Au}^{3+}$ have the same electronic structure and are right next to each other the periodic table, forming a good pair for comparison. In addition, we also studied $\mathrm{T}_{15}$ reacting with $\mathrm{Hg}^{2+}$ and $\mathrm{C}_{15}$ with $\mathrm{Ag}^{+}$. All the DNA 20 samples contain a fluorophore label on the $5^{\prime}$-end and the products were analyzed by denaturing gel electrophoresis. For the cisplatin/AF-A $\mathrm{A}_{15}$ mixture $(\mathrm{AF}=$ Alexa Fluor 647), the free DNA has the highest mobility (first lane, Figure 1B). The PtDNA adducts migrate more slowly in the presence of higher 25 concentration of cisplatin, suggesting more cisplatin molecules are associated with the DNA. ${ }^{31}$ We emphasize that the cisplatin adduct is stable enough to survive the denaturing gel conditions (e.g. $8 \mathrm{M}$ urea and strong electric field). The decreased DNA mobility suggests that the DNA carries fewer 30 negative charges after reacting with cisplatin. This is reasonable since replacing the chloride ligand with a charge neutral adenine gives rise to a positive charge (Figure 1E). Mixing $\mathrm{HAuCl}_{4}$ with DNA, on the other hand, did not result in a change in the gel mobility; only quenched fluorescence 35 was observed at high gold concentrations (Figure 1C). The lack of mobility change is likely due to instability of the AuDNA adduct in the gel. To understand fluorescence quenching, we mixed FAM-A 15 with $\mathrm{HAuCl}_{4}$ in solution (Figure S1), where fluorescence quenching was also observed. ${ }_{40}$ The quenched fluorescence was recovered by adding KCN, which is a strong ligand for gold. On the other hand, adding $\mathrm{HAuCl}_{4}$ to the free fluorescein fluorophore (no DNA) did not produce much fluorescence quenching. Therefore, $\mathrm{HAuCl}_{4}$ does not bind to the fluorophore itself but forms adducts with 45 the poly-A DNA to quench fluorescence. FAM-C ${ }_{15}$ was also tested with $\mathrm{HAuCl}_{4}$ and little shift in gel was also observed either (Figure S2). The $\mathrm{Ag}^{+} / \mathrm{FAM}-\mathrm{C}_{15}$ and $\mathrm{Hg}^{2+} / \mathrm{AF}-\mathrm{T}_{15}$ mixtures migrated at the same speed as the metal free samples too, and only $\mathrm{Hg}^{2+}$ resulted in moderate quenching at high 50 concentration (Figure 1D, E). This study indicates that out of the four tested combinations, only the cisplatin adduct is stable enough to be qualified as metallated DNA. It is known that cisplatin binds to guanine even more strongly. We chose to study poly-A DNA since it does not suffer from artifacts 55 that may arise from guanine quadruplex structures.
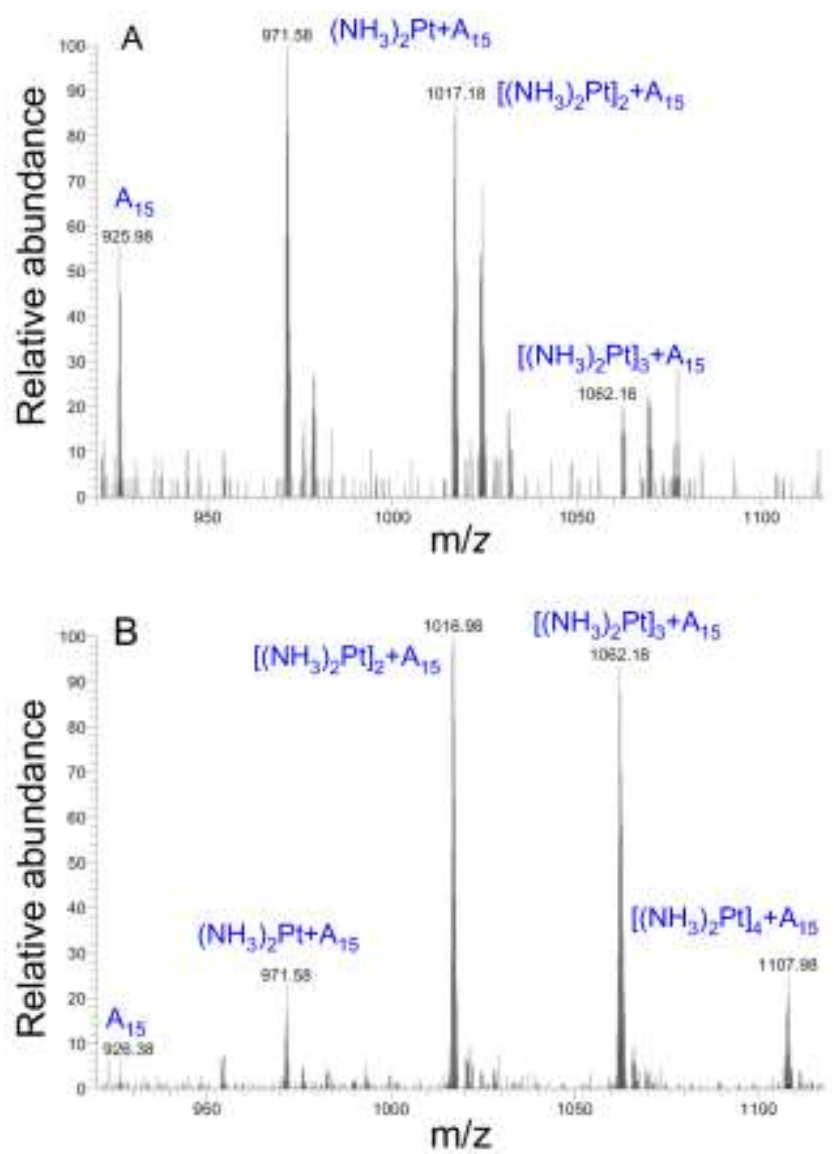

Figure 2. Mass spectrum of $\mathrm{A}_{15}(20 \mu \mathrm{M})+$ cisplatin $(100 \mu \mathrm{M})$ ${ }_{60}$ incubated for $6 \mathrm{~h}(\mathrm{~A})$ and $50 \mathrm{~h}(\mathrm{~B})$. The region of species in mass spectrometer with 5 negative charges is shown.

To quantify the number of Pt associated with each DNA, we performed mass spectrometry experiments, in which 20 ${ }_{65} \mu \mathrm{M} \mathrm{A}_{15}$ DNA was incubated with $100 \mu \mathrm{M}$ cisplatin. After $6 \mathrm{~h}$ reaction (Figure 2A), a strong peak of free DNA can still be observed; mono and dual platinated DNAs are the main species. After $50 \mathrm{~h}$ incubation (Figure 2B), the free DNA peak disappeared and 2 or $3 \mathrm{Pt}$ adducts are the main species. We 70 used a ratio of cisplatin:DNA $=5: 1$, and the highest platinated DNA contains just $4 \mathrm{Pt}$. The mass spectra of the free DNA 
and the isotope effects are shown in Figure S3 and S4. The mass spectrometry results indicate that the reaction between DNA and cisplatin is quite slow.

Fast adsorption by GO. Our above experiments indicate that 5 the Pt-DNA adduct is stable and might be used as a new polymer for further studies. Previous work showed that the melting temperature $\left(T_{\mathrm{m}}\right)$ of a DNA duplex is decreased by a cisplatin adduct in most buffer condition. ${ }^{32}$ However, with very low salt concentration (e.g. $<1 \mathrm{mM} \mathrm{NaCl}$ ), the cisplatin 10 adduct can slightly increase the $T_{\mathrm{m}}$ as well. ${ }^{33}$ Cisplatin also bends duplex DNA by bridging two adjacent guanines. ${ }^{34}$ Most of the previous works involved double-stranded DNA. In this work, we study the property of ss-DNA. Since platinated DNA bases carry a positive charge (Figure 1F), it might be 15 useful for enhancing the interaction between DNA and negatively charge materials. In this study, we used graphene oxide (GO) for proof-of-concept.

Graphene is a newly discovered nanomaterial with many interesting properties. To disperse in water, GO with carboxyl 20 and hydroxyl groups is often used. GO effectively adsorbs single-stranded DNA and acts as a fluorescence quencher at the same time, and fluorescently labeled probe DNA has been used as a sensor for DNA detection. ${ }^{35-39}$ In the presence of cDNA, the probe is desorbed from the GO surface to enhance 25 fluorescence signal. For this application, the probe DNA needs to be adsorbed strongly enough to give a stable background signal but weakly enough to be quickly desorbed by the cDNA. For other applications, it might be desirable to have more stable adsorption (e.g. irreversible). Although 30 covalent linkage can be achieved by forming amide bonds using amino modified DNA, most DNA can only be attached to the edge of GO, where carboxyl groups are located. ${ }^{40,41}$ In addition, it is difficult to wash away non-covalently linked DNA. ${ }^{42}$ If a strong and stable physisorption can be achieved, 35 many more applications can be enabled. We aim to test whether platinated DNA can be used for this purpose and DNA adsorption was first studied as schematically shown in Figure 3A.

To enhance electrostatic interaction, the DNA adsorption 40 experiment was first carried out in the absence of salt (i.e. low ionic strength). To achieve platination, $\mathrm{AF}-\mathrm{A}_{15}$ was incubated with cisplatin for various amount of time. A longer incubation corresponds to more cisplatin attached, as indicated by our gel and mass spectrometry studies. The fluorescence of these 45 samples was monitored for $5 \mathrm{~min}$ before GO was added (Figure 3B). Without cisplatin treatment, the DNA was not adsorbed by GO since no fluorescence quenching was observed (blue line). This is because both DNA and GO are negatively charged and they strongly repel each other in the ${ }_{50}$ low salt buffer. After longer incubation with cisplatin, we observed progressively faster DNA adsorption. With $4 \mathrm{~h}$ incubation, fluorescence went to the background level in $~ 10$ min after mixing with GO, suggesting complete adsorption. As a control experiment, AF- $\mathrm{T}_{15}$ was treated with cisplatin the 55 same way and then mixed with GO. The fluorescence did not change much even after incubating with cisplatin for $4 \mathrm{~h}$ (Figure 2C). This is consistent with the low affinity between thymine and cisplatin. Therefore, cisplatin has to covalently bind to DNA to be effective; it cannot act as a salt for non${ }_{60}$ specific charge screening. This also confirms that Pt addition has reduced the number of negative charges on DNA, facilitating its interaction with GO.
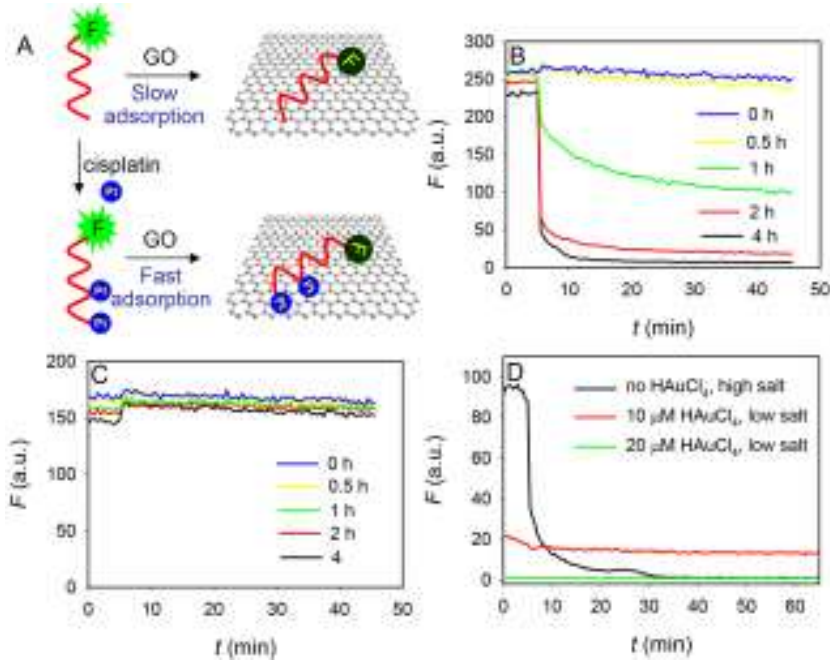

${ }_{65}$ Figure 3. (A) A scheme of fluorescently labeled DNA and platinated DNA adsorption by GO in low salt buffer. Adsorption results in fluorescence quenching. Kinetics of cisplatin treated $\mathrm{AF}_{-\mathrm{A}_{15}}$ (B) and $\mathrm{AF}_{-15}$ (C) adsorption by GO. (D) Adsorption of AF- $\mathrm{A}_{15}$ after $\mathrm{HAuCl}_{4}$ treatment in low 70 salt buffer or non-treated DNA in high salt buffer.

Adding a positive charge to DNA bases can also be realized by lowering $\mathrm{pH}$ to protonate adenine $\left(\mathrm{pK}_{\mathrm{a}}=3.5\right)$ and cytosine $\left(\mathrm{pK}_{\mathrm{a}}=4.2\right)$. This method was used for assisting DNA 75 adsorption to gold, ${ }^{43,44}$ silver, ${ }^{45}$ and GO previously. ${ }^{46}$ Even though DNA is still overall negatively charged, the cationic bases can significantly change the interaction kinetics and stability of DNA with surfaces. In the case of platinated DNA, the fast DNA adsorption reaction was achieved at neutral $\mathrm{pH}$.

${ }_{80} \mathrm{As}$ a control experiment, the same reaction was performed with $\mathrm{HAuCl}_{4}$ treated AF-A15. With $10 \mu \mathrm{M} \mathrm{HAuCl} 4$ (Au:AF$\mathrm{A}_{15}=5: 1$ ), the fluorescence was quenched by $80 \%$ (Figure $3 \mathrm{D}$, red curve), suggesting the association of Au to the DNA. However, addition of $\mathrm{GO}$ at $5 \mathrm{~min}$ did not induce much 85 further quenching, indicating the lack of DNA adsorption. Further increase of gold concentration resulted in complete fluorescence quenching (green curve), disallowing us to study its adsorption by $\mathrm{GO}$. It might be that $\mathrm{AuCl}_{4}{ }^{-}$originally carries a negative charge and binding to DNA makes it charge neutral 90 and it does not assist DNA adsorption. It needs to be noted that achieving DNA adsorption by GO is not a difficult task. For example, by using a high ionic strength buffer (black curve, Figure 3D), fast DNA adsorption was observed in the absence of gold or platinum. We did most of the adsorption ${ }_{95}$ experiments in the absence of salt to highlight the electrostatic effect of platination.

Highly stable conjugates. The above experiments have established the kinetic advantage of using Pt-DNA to attach to ${ }_{100} \mathrm{GO}$ under low salt conditions. For many applications, it is more important to have a stable DNA/GO conjugate. ${ }^{42,47,48}$ 
Next, we compared adsorption affinity between unmodified and cisplatin treated AF-A 15 . To facilitate adsorption of unmodified DNA, a buffer with high salt concentration was used. Then both systems were treated with molecules that 5 might compete with the adsorbed DNA in a real sample matrix. The scheme of the displacement reaction is shown in Figure 4A, where displaced DNA produces fluorescence signal. After adding non-labeled $A_{15}$ DNA, significant fluorescence enhancement was observed for the unmodified 10 DNA/GO complex but the cisplatin treated DNA remained stably adsorbed (Figure 4B). Similar observations were made with bovine serum albumin (BSA, Figure 4C) and with a surfactant (Triton X-100, Figure 4D). When a thiol containing peptide, GSH, was added, no DNA displacement was 15 observed for either sample (Figure 4E). We used GSH since it might bind to platinum and thus weaken the DNA adsorption affinity. This set of experiments established the thermodynamic stability of the platinated DNA/GO interaction.

20 Of note, although cisplatin might directly react with carboxyl groups (such as those on GO), this is unlikely to happen in our system. We first reacted cisplatin with DNA, and the Pt center was coordinated by strong ammonia and adenine. Therefore, weaker carboxyl ligands are unlikely to 25 displace these stronger ones. We attribute the stable adsorption of cisplatin treated DNA to charge interaction instead of using Pt as a covalent bridge to link DNA and GO. For practical application, the affinity is strong enough to survive harsh conditions that might be encountered in 30 challenging applications.
A
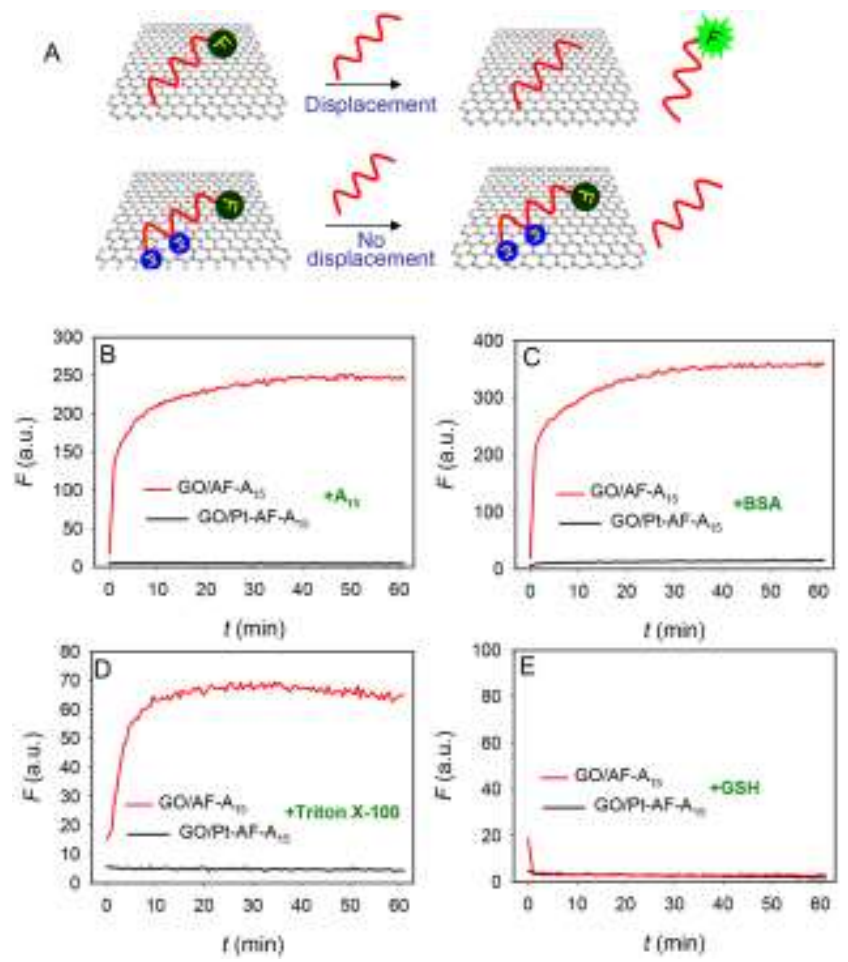

Figure 4. (A) Schematics showing adsorbed DNA can be easily displaced, resulting in fluorescence enhancement, while 35 platinated DNA is stably adsorbed. Kinetics of DNA displacement by adding $\mathrm{A}_{15}$ (B), BSA (C), Triton X-100 (D) and GSH (E). Increased fluorescence is due to displacement of adsorbed DNA probes.

${ }_{40}$ DNA Hybridization on GO. This highly efficient and stable adsorption of Pt-DNA by GO might lead to useful applications. In addition to making biosensors, DNA/GO complexes have also been used for assembling nanomaterials. In this case, a high affinity between DNA and GO is needed. ${ }_{45}$ Since the binding affinity of poly-A DNA to GO is higher than that for poly-T DNA, a poly-A block was used to anchor on GO. ${ }^{49}$ Despite such applications, as we shown here, it is still possible to displace adsorbed DNA by various types of competing molecules, producing background signal. These so problems might be alleviated by using platinated DNA. To test the function of adsorbed platinated DNA, we designed a sequence of $\mathrm{A}_{15} \mathrm{~T}_{30}$. Since cisplatin selectively reacts with the adenine base, this platinated di-block DNA should stably anchor on the GO surface using the poly-A block, and the ${ }_{55}$ poly- $\mathrm{T}$ part is still available for hybridization (Figure $5 \mathrm{~A}$ ). Indeed, as shown in Figure $5 \mathrm{~B}$, the Pt-DNA/GO conjugate effectively hybridized with FAM-A 30 , since the sample was highly fluorescent under microscope. For comparison, the same DNA without cisplatin treatment or the FAM-A 30 alone ${ }_{60} \mathrm{did}$ not produce noticeable fluorescence. A transmission micrograph of the GO sheets is shown in Figure S5. Note we used a low salt buffer for the DNA adsorption step; the lack of fluorescence is mainly attributed to the failure of immobilizing non-platinated $\mathrm{A}_{15} \mathrm{~T}_{30}$ DNA. When the 65 adsorption step was carried out in a high salt buffer (Figure $5 \mathrm{C}$ ), the fluorescence signal was still much stronger with the cisplatin treated DNA, suggesting a much higher DNA density on the GO surface. This experiment indicates that Pt-DNA can form a stable conjugate with GO and the remaining DNA 70 fragment is still functional as a normal DNA probe for hybridization.
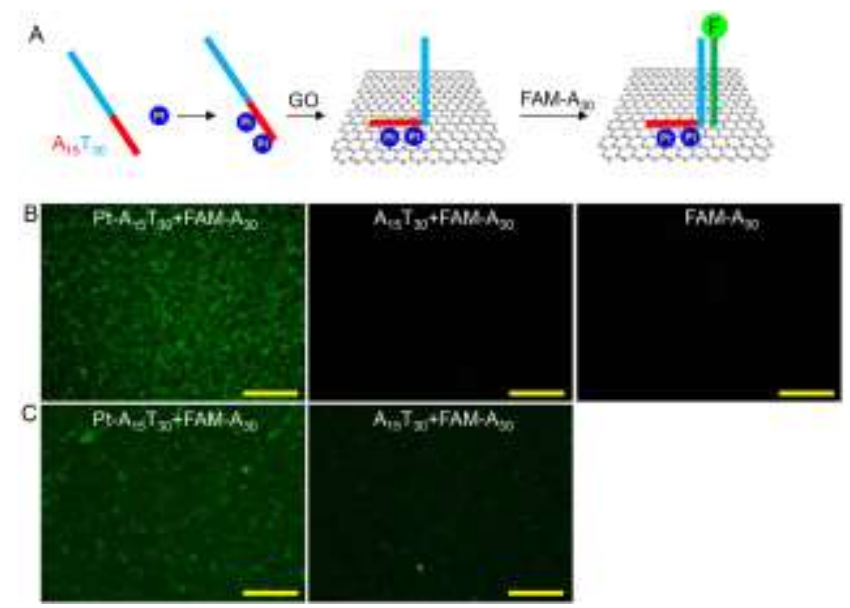

75 Figure 5. Schematics of reacting a Pt-DNA with GO and its further hybridization with FAM-labeled DNA to make the GO surface fluorescent. Fluorescence micrographs when DNA adsorption on GO was at low salt concentration (B) and at high salt buffer (C). Scale bars $=1 \mathrm{~mm}$.

80

\section{Conclusions.}


In summary, we compared the stability of complexes formed between DNA and a few transition metals and metal complexes. Among these, the adduct formed between cisplatin and DNA has the highest stability and can be used as a new 5 metal containing polymer. This adduct shows fast adsorption by GO and forms a very stable adsorption complex. This is attributed to the positive charges brought by bonding the $\mathrm{Pt}$ center to the DNA bases. This system allows a much higher DNA density on the GO surface, while still retaining the 10 hybridization property of DNA probes. This work suggests that metallated DNA is a new type of metal containing polymer with useful properties for analytical and biomedical applications.

\section{MATERIALS AND METHODS}

Chemicals. All the DNA samples were purchased from Integrated DNA Technologies Inc. (IDT, Coralville, IA). The non-labeled and FAM-labeled DNAs were purified by standard desalting. The AF-labeled DNAs were purified by 20 HPLC. GO was purchased from ACS Material, LLC (Medford, MA). Chloroauric acid trihydrate was purchased from Fisher Scientific. Cis-diammineplatinum(II) dichloride (cisplatin), mercury(II) perchlorate, silver nitrate, Triton X100, glutathione (GSH) and bovine serum albumin (BSA) 25 were from Sigma-Aldrich. Tetramethylethylenediamine (TEMED), urea, ammonium persulfate (APS) and acrylamide/bis-acrylamide (29:1) solution 40\% (w/v) were obtained from Bio Basic Inc (Markham, ON, Canada). Sodium citrate and 4-(2-hydroxyethyl)-1-piperazineethanesulfonic 30 acid (HEPES) were purchased from Mandel Scientific Inc (Guelph, ON, Canada). Milli-Q water was used to prepare all the buffers and solutions.

DNA adsorption kinetics. To measure the adsorption kinetics of AF-A $15 /$ cisplatin adduct by GO, the adduct was first 35 prepared by mixing $\mathrm{AF}-\mathrm{A}_{15}(2 \mu \mathrm{M})$ and cisplatin $(1 \mathrm{mM})$ for different incubation time $(0,0.5,1,2,4 \mathrm{~h})$. Then $2 \mu \mathrm{L}$ of the mixtures were respectively added to $98 \mu \mathrm{L}$ HEPES $(10 \mathrm{mM}$, $\mathrm{pH}$ 7.6) and the samples were monitored for 5 min using a SpectraMax M3 microplate reader by exciting at $640 \mathrm{~nm}$ 40 (emission at $668 \mathrm{~nm})$. Then $2 \mu \mathrm{L}$ nano-GO $\left(500 \mu \mathrm{g} \mathrm{mL}^{-1}\right)$ was added to the mixtures and the samples were monitored for another $40 \mathrm{~min}$. AF- $\mathrm{T}_{15} /$ cisplatin was also prepared for comparison. To adsorb AF-A 15 in high salt buffer, $2 \mu \mathrm{L}$ AF$\mathrm{A}_{15}(2 \mu \mathrm{M})$ was added to $98 \mu \mathrm{L}$ HEPES $(10 \mathrm{mM}, \mathrm{pH} 7.6)$ with ${ }_{45} 100 \mathrm{mM} \mathrm{NaCl}$ and $2 \mathrm{mM} \mathrm{MgCl}_{2}$. The samples were monitored for $5 \mathrm{~min}$ and then $2 \mu \mathrm{L}$ nano-GO $\left(500 \mu \mathrm{g} \mathrm{mL}^{-1}\right)$ was added. The method for preparing nano-GO was described previously. \{Wang, 2013 \#11202\}

DNA desorption kinetics. To understand desorption, AF-A 15 ${ }_{50}(2 \mu \mathrm{M})$ was mixed with cisplatin $(1 \mathrm{mM})$ for $16 \mathrm{~h}$. Then, 10 $\mu \mathrm{L}$ of the $\mathrm{AF}-\mathrm{A}_{15} /$ cisplatin mixture was added to $90 \mu \mathrm{L}$ HEPES $(10 \mathrm{mM})$ for $5 \mathrm{~min}$ and $2 \mu \mathrm{L}$ nano-GO $\left(500 \mu \mathrm{g} \mathrm{mL}^{-1}\right)$ was added. After $60 \mathrm{~min}$, the buffer was adjusted to contain a final of $100 \mathrm{mM} \mathrm{NaCl}$ and $2 \mathrm{mM} \mathrm{MgCl}_{2}$. To test the 55 displacement, $5 \mu \mathrm{L} \mathrm{A}_{15}(100 \mathrm{mM})$, BSA (100 mg mL $\left.{ }^{-1}\right), \mathrm{GSH}$ $(200 \mathrm{mM})$ or Triton X-100 (1\%) were respectively added and the samples were monitored for another $60 \mathrm{~min}$. As a control group, the desorption kinetics of $\mathrm{AF}-\mathrm{A}_{15}$ with nano-GO were also investigated under the same condition. To test whether ${ }_{60} \mathrm{AF}-\mathrm{A}_{15} / \mathrm{Au}$ can be adsorbed by nano-GO, $\mathrm{AF}-\mathrm{A}_{15} / \mathrm{Au}$ was prepared by mixing $\mathrm{AF}-\mathrm{A}_{15}(2 \mu \mathrm{M})$ with $\mathrm{HAuCl}_{4}(10$ or 20 $\mu \mathrm{M}$ ) for $1 \mathrm{~h}$. Other procedures were the same as for the cisplatin samples.

DNA hybridization on GO. For the data shown in Figure 5B 65 (low salt adsorption), $5 \mu \mathrm{L}$ of $100 \mu \mathrm{M} \mathrm{A}_{15} \mathrm{~T}_{30}$ was mixed with $100 \mu \mathrm{L}$ of $1 \mathrm{mM}$ cisplatin in Milli-Q water for $16 \mathrm{~h}$ at room temperature. Then $10 \mu \mathrm{L}$ GO $\left(500 \mu \mathrm{g} \mathrm{mL}^{-1}\right)$ was added to this solution and incubated for another hour. After centrifugation at $15,000 \mathrm{rpm}$ for $10 \mathrm{~min}$ and washed by HEPES $(10 \mathrm{mM}, \mathrm{pH}$ 70 7.6) twice, the Pt-DNA/GO complex was re-suspended in 100 $\mu \mathrm{L}$ high salt buffer A (100 mM HEPES, $300 \mathrm{mM} \mathrm{NaCl}, 4 \mathrm{mM}$ $\left.\mathrm{MgCl}_{2}\right) .5 \mu \mathrm{L}$ FAM-A $30(10 \mu \mathrm{M})$ was then added to the sample and incubated for $1 \mathrm{~h}$. After that, the mixture was centrifuged at $15,000 \mathrm{rpm}$ for $10 \mathrm{~min}$ and washed by buffer A twice. The 75 sample was prepared by pipetting a drop of the aqueous solution onto the coverslip and visualized under an inverted epi-fluorescence microscope (Eclipse Ti-S, Nikon) with a CCD camera (Qimaging Retiga 2000R Fast 1394). For comparison, $10 \mu \mathrm{L}$ GO $\left(500 \mu \mathrm{g} \mathrm{mL}^{-1}\right)$ was directly added to ${ }_{80}$ either $100 \mu \mathrm{L} 5 \mu \mathrm{M} \mathrm{A}_{15} \mathrm{~T}_{30}$ dissolved in water or just Milli-Q water. For data in Figure 5C (high salt adsorption), $5 \mu \mathrm{L}$ of $100 \mu \mathrm{M} \mathrm{A}_{15} \mathrm{~T}_{30}$ was mixed with $100 \mu \mathrm{L}$ of $1 \mathrm{mM}$ cisplatin in Milli-Q water for $16 \mathrm{~h}$ at room temperature. Then $10 \mu \mathrm{L} \mathrm{GO}$ (500 $\mu \mathrm{g} \mathrm{mL}^{-1}$ ) was added to this solution and high salt 85 solution was obtained by adding salt to a solution with high salt (100 mM HEPES, $\left.300 \mathrm{mM} \mathrm{NaCl}, 4 \mathrm{mM} \mathrm{MgCl}_{2}\right)$. The mixture was incubated for $1 \mathrm{~h}$. As comparison, $10 \mu \mathrm{L}$ GO (500 $\mu \mathrm{g} \mathrm{mL}^{-1}$ ) was added to $100 \mu \mathrm{L} 5 \mu \mathrm{M} \mathrm{A}_{15} \mathrm{~T}_{30}$ dissolved in buffer $\mathrm{A}$ and incubated for another hour. Other procedures 90 were the same as for the low salt adsorption.

\section{Acknowledgement}

We thank the mass spectrometry facility at the University of Waterloo and the assistance of Dr. Richard Smith. Funding for 95 this work is from the University of Waterloo, the Canadian Foundation for Innovation, the Natural Sciences and Engineering Research Council (NSERC) of Canada and the Early Researcher Award from Ontario MRI.

\section{Notes and references}

$100{ }^{a}$ Department of Chemistry, Waterloo Institute for Nanotechnology, University of Waterloo, Waterloo, Ontario, N2L 3G1, Canada. Fax: 519 7460435; Tel: 5198884567 Ext. 38919; E-mail: liujw@uwaterloo.ca. $\dagger$ Electronic Supplementary Information (ESI) available: [methods, additional gels, kinetics, mass spectrum]. See DOI: 10.1039/b000000x/

105

1. R. R. Breaker, Nature, 2004, 432, 838.

2. A. T. Krueger, H. G. Lu, A. H. F. Lee and E. T. Kool, Acc. Chem. Res., 2007, 40, 141-150.

3. R. K. O. Sigel and H. Sigel, Acc. Chem. Res., 2010, 43, 974-984.

110 4. A. Ono and H. Togashi, Angew. Chem., Int. Ed., 2004, 43, 43004302.

5. A. Ono, S. Cao, H. Togashi, M. Tashiro, T. Fujimoto, T. Machinami, S. Oda, Y. Miyake, I. Okamoto and Y. Tanaka, Chem. Comm., 2008, 4825-4827.

115 6. S. Verma, A. K. Mishra and J. Kumar, Acc. Chem. Res., 2009, 43, 79-91.

7. R. R. Breaker and G. F. Joyce, Chem. Biol., 1994, 1, 223-229.

8. J. Li, W. Zheng, A. H. Kwon and Y. Lu, Nucleic Acids Res., 2000, 28, 481-488. 
9. M. Rajendran and A. D. Ellington, Anal. Bioanal. Chem., 2008, 390, 1067-1075.

10. S. W. Santoro, G. F. Joyce, K. Sakthivel, S. Gramatikova and C. F. Barbas, III, J. Am. Chem. Soc., 2000, 122, 2433-2439.

5 11. M. Hollenstein, C. Hipolito, C. Lam, D. Dietrich and D. M. Perrin, Angew. Chem., Int. Ed., 2008, 47, 4346 - 4350.

12. J. Liu, A. K. Brown, X. Meng, D. M. Cropek, J. D. Istok, D. B. Watson and Y. Lu, Proc. Natl. Acad. Sci. U.S.A., 2007, 104, 20562061.

10 13. V. Dokukin and S. K. Silverman, Chem. Sci., 2012, 3, 1707-1714.

14. P.-J. J. Huang, J. Lin, J. Cao, M. Vazin and J. Liu, Anal. Chem., 2014, 86, 1816-1821.

15. A. Dorcier, P. J. Dyson, C. Gossens, U. Rothlisberger, R. Scopelliti and I. Tavernelli, Organometallics, 2005, 24, 2114-2123.

15 16. D. V. Deubel and H. T. Chifotides, Chem. Comm., 2007, 3438-3440.

17. D. M. J. Lilley and E. Palecek, EMBO J., 1984, 3, 1187-1192.

18. Y. W. Jung and S. J. Lippard, Chem. Rev., 2007, 107, 1387-1407.

19. T. Boulikas and M. Vougiouka, Oncol. Rep., 2003, 10, 1663-1682.

20. X. Y. Wang and Z. J. Guo, Dalton T., 2008, 1521-1532.

20 21. B. Rosenberg, L. Vancamp, J. E. Trosko and V. H. Mansour, Nature, 1969, 222, 385-386.

22. E. R. Jamieson and S. J. Lippard, Chem. Rev., 1999, 99, 2467-2498.

23. E. Braun, Y. Eichen, U. Sivan and G. Ben-Yoseph, Nature, 1998, 391, 775-778.

25 24. H. Yan, S. H. Park, G. Finkelstein, J. H. Reif and T. H. LaBean, Science, 2003, 301, 1882-1884.

25. G. M. Zhang, S. P. Surwade, F. Zhou and H. T. Liu, Chem. Soc. Rev., 2013, 42, 2488-2496.

26. K. Strothkamp and S. J. Lippard, Biophys. J., 1976, 16, A145-A145.

30 27. M. Kwak and A. Herrmann, Angew. Chem. Int. Ed., 2010, 49, 85748587.

28. G. R. Whittell, M. D. Hager, U. S. Schubert and I. Manners, Nat. Mater., 2011, 10, 176-188.

29. G. L. Eichhorn and Y. A. Shin, J. Am. Chem. Soc., 1968, 90, 73237328.

30. D. V. Deubel, J. Am. Chem. Soc., 2002, 124, 5834-5842.

31. F. Wang, P.-J. J. Huang and J. Liu, Chem. Comm., 2013, 49, 94829484.

32. C. J. Van Garderen, L. P. A. Van Houte, H. Van den Elst, J. H. Van $40 \quad$ Boom and J. Reedijk, J. Am. Chem. Soc., 1989, 111, 4123-4125.

33. R. Zaludova, V. Kleinwachter and V. Brabec, Biophys. Chem., 1996, 60, $135-142$.

34. S. F. Bellon and S. J. Lippard, Biophys. Chem., 1990, 35, 179-188.

35. C. H. Lu, H. H. Yang, C. L. Zhu, X. Chen and G. N. Chen, Angew. 45 Chem. Int. Ed., 2009, 48, 4785-4787.

36. S. J. He, B. Song, D. Li, C. F. Zhu, W. P. Qi, Y. Q. Wen, L. H. Wang, S. P. Song, H. P. Fang and C. H. Fan, Adv. Funct. Mater., 2010, 20, 453-459.

37. Y. Wang, Z. H. Li, J. Wang, J. H. Li and Y. H. Lin, Trends Biotechnol., 2011, 29, 205-212.

38. H. Wang, R. H. Yang, L. Yang and W. H. Tan, ACS Nano, 2009, 3, 2451-2460.

39. B. Liu, Z. Sun, X. Zhang and J. Liu, Anal. Chem., 2013, 85, $7987-$ 7993.

55 40. A. Lerf, H. He, M. Forster and J. Klinowski, J. Phys. Chem. B, 1998, 102, 4477-4482.

41. K. A. Mkhoyan, A. W. Contryman, J. Silcox, D. A. Stewart, G. Eda, C. Mattevi, S. Miller and M. Chhowalla, Nano Lett., 2009, 9, 10581063.

60 42. P.-J. J. Huang and J. Liu, Anal. Chem., 2012, 84, 4192-4198.

43. X. Zhang, M. R. Servos and J. Liu, J. Am. Chem. Soc., 2012, 134, $7266-7269$.

44. X. Zhang, B. Liu, N. Dave, M. R. Servos and J. Liu, Langmuir, 2012, 28, $17053-17060$

65 45. X. Zhang, M. R. Servos and J. Liu, Chem. Comm., 2012, 48, 1011410116.

46. P.-J. J. Huang, R. Kempaiah and J. Liu, J. Mater. Chem., 2011, 21, 8991-8993.

47. Y. Guo, L. Deng, J. Li, S. Guo, E. Wang and S. Dong, ACS Nano, 2011, 5, 1282-1290.

48. X. Tan, T. Chen, X. Xiong, Y. Mao, G. Zhu, E. Yasun, C. Li, Z. Zhu and W. Tan, Anal. Chem., 2012, 84, 8622-8627.
49. L. H. Tang, Y. Wang, Y. Liu and J. H. Li, ACS Nano, 2011, 5, $3817-$ 3822 .

75 